Geront. clin. 1966;8:2-3

\title{
Professor F. Verzár In Honour of his Eighieth Birthday
}

Prof. Fritz Verzár celebrates his eightieth birthday this year. Gerontologia clinica owes much to his inspiration and pratical help. His work has inspired most of the workers in the field of gerontology including those who have contributed to this issue. The Editorial Board congratulates him on the happy occasion and wishes him many successful years to come. Professor F. Verzár In Honour of his Eighieth Birthday

Few octogenarians can have had such a varied and distinguished scientific life as Professor F. Verzár. After a noteworthy career as a Physiologist he has, during the past 20 years, established an equally sound reputation as a Gerontologist. Korenchevsky, Bourlière, Brull, Cowdry, Shock and F. Verzár developed the study of gerontology and it is largely as a result of their efforts that gerontology and geriatrics are accepted as worthy fields of study today.

The early work of Professor F. Verzár in this field was done in conjunction with his wife on the differing behaviour of young and old rats. Later he extended his researches to the study of collagen and devised a number of ingenious techniques for the study of the physical properties of collagen.

There can hardly have been a major symposium, seminar, conference or congress in gerontology during the past 15 years that Professor F. Verzár has not attended. His enthusiasm and friendliness and his general appreciation of the researches of younger colleagues has won for him many friends and has contributed very considerably to the happy atmosphere of the discussions at numerous symposia and seminars.

Few can appreciate the enormous amount of time and effort that he has given to the editing of Gerontologia. The success of this journal and the growing reputation that it has among scientific journals, are entirely due to his efforts. No paper is lightly turned down, although it may have to be re-written under his wise guidance and numerous contributors can testify to the courteous, kindly yet firm treatment they have received at his hands.

If ever an example were needed of retirement from ones official appointment leading to a burst of new energy and the establishing of a new career, Professor F. Verzár is the example par excellence.

With such abounding energy still present his many friends may hope to continue to share his friendship and he the companionship of his family and the greater fulfilment of his own work. February, 1966

R. E. Tunbridge 


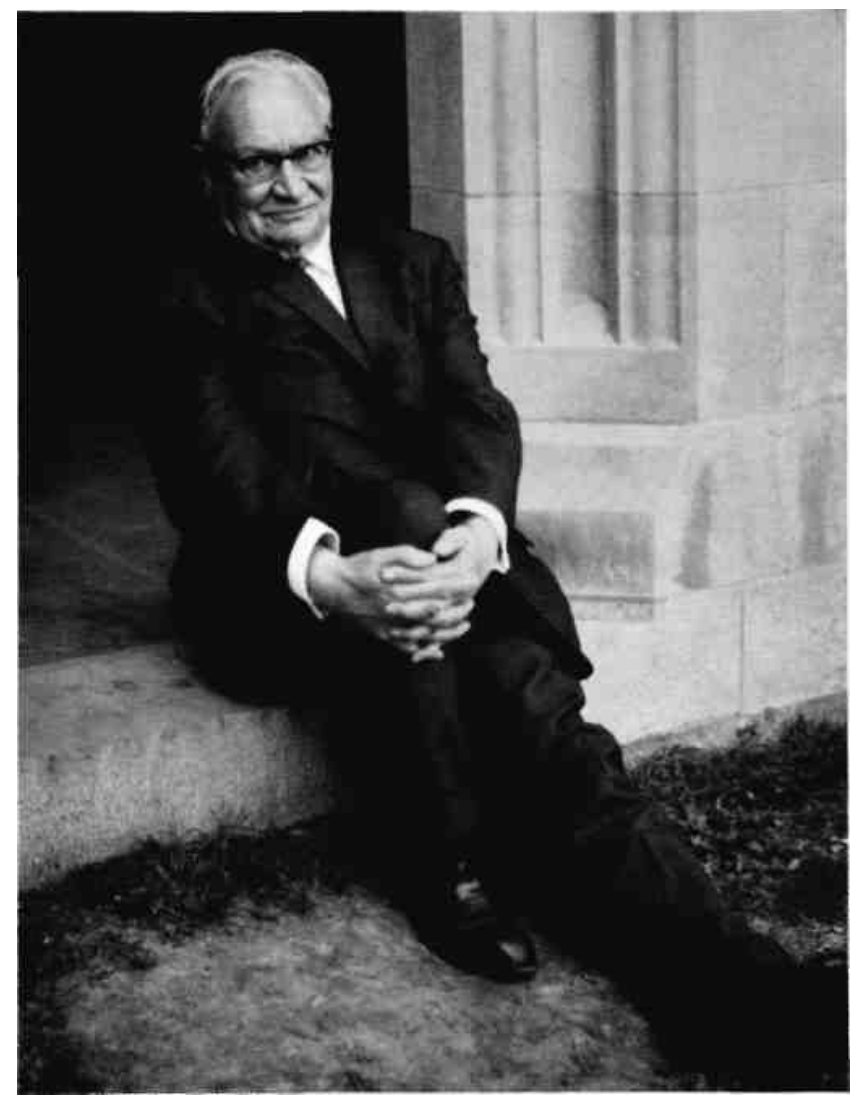

